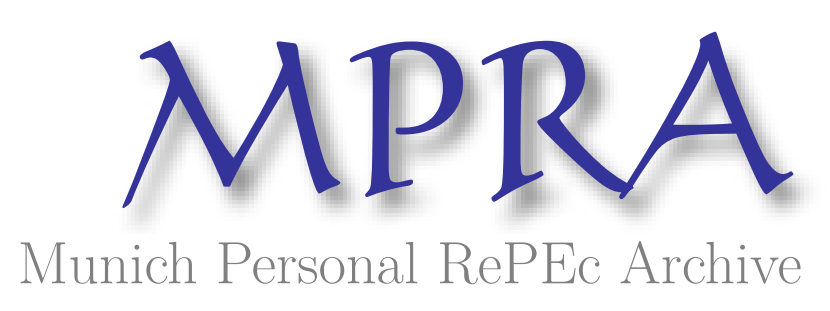

\title{
Price-Controls in Jewish Law
}

Makovi, Michael

24 March 2016

Online at https://mpra.ub.uni-muenchen.de/72821/

MPRA Paper No. 72821, posted 02 Aug 2016 08:28 UTC 
"Price-Controls in Jewish Law"

Michael Makovi

michael.makovi@ttu.edu / mbmakovi@gmail.com

$\mathrm{PhD}$ student in Agricultural and Applied Economics (AAEC) at Texas Tech University (TTU).

Research assistant with the Free Market Institute (FMI) at TTU.

Abstract: Previous scholarship has explored whether the halakhah (Jewish law) of ona'ah (fraud) constitutes a price-control. However, less attention has been paid to the similar law of hayyei nefesh (essential foodstuffs) - also known as hafka'at she'arim (profiteering). Nor has criticism been directed towards arbitrary price-controls imposed by the corporate, democratic Jewish community. This essay argues that while ona'ah is $\underline{\text { not }}$ a price-control, hayyei nefesh / hafka'at she'arim $\underline{i s}$ one. Economic theory demonstrates that like all price-controls, hayyei nefesh / hafka'at she'arim and corporate communal price-controls are both self-defeating because the means conflict with the ends sought. The conflict between religion and science is therefore not limited to cosmology and biology, but may include economics as well.

Keywords: price controls; price fixing; just price; jewish business ethics; religious economics JEL Codes: A12, B11, D00, K20, P00, Z12

It is almost universally accepted among economists today that price-controls are almost always self-defeating, accomplishing the opposite of their intention, and generally producing perverse, undesirable consequences. Concerning price-controls both ancient (Schuettinger and Butler 1979) and modern (Coyne and Coyne 2015a), the consensus is nearly unanimous that price-controls simply do not work (Morton 2001, Rockoff 2008).

But relatively little attention has been paid to price-controls in Jewish law (halakhah). This 
essay will examine three halakhot (pl.) in particular, viz.: (1) ona'ah (fraud); (2) hayyei nefesh (“essential foodstuffs") - also called hafka'at she'arim ("profiteering”); and (3) price-controls imposed arbitrarily by the corporate Jewish community. We shall see that on the one hand, ona'ah does $\underline{\text { not }}$ constitute a price-control at all, even though it superficially appears to be one. On the other hand, hayyei nefesh and the corporate communal controls $\underline{d o}$ constitute forms of price-control. Furthermore, the typical, mainstream arguments against price-controls apply with full-force to these latter laws.

The fact that several Jewish laws are open to positive (value-free) scientific criticism by economists poses an obvious dilemma for the Orthodox or traditionally observant Jew. It is conventional to accept the possibility of conflict between religion and cosmology and biology (evolution), ${ }^{1}$ but it is not usually realized that a similar conflict can exist between religion and economic science. Because hayyei nefesh and the communal controls are forms of price-control, and because economic science demonstrates price-controls to be generally self-defeating, therefore, we shall see that religion and positive science may conflict not only in the realm of cosmology or biology, but even in the field of economics and public policy as well. We will suggest several possible means of reconciling this conflict.

We will analyze Jewish law as a single, continuous whole, considering the Roman-era Mishnah, the Sassanid-era Talmud, and the Medieval codes of Jewish law as explaining each other. In other words, we are interested in what living Jewish law has to say for practical matters, rather than being concerned with what the historical Mishnah or Talmud meant. There is an important distinction to be drawn between the two approaches: on the one hand, one could isolate specific statements in the Mishnah or Talmud and situate them in their historical contexts according to the identities of their named-authors. On the other hand, one may consider Jewish literature as a continuous unity and study it in a relatively ahistorical fashion. Kleiman's study of ona'ah takes the historical approach and notes that other scholars have taken the unity approach (Kleiman 1987: 25 n. 2). This essay will take the unity approach, for our concern is not with what the specific authors of the Mishnah or Talmud meant 
as individuals, but instead with how living, evolving Jewish law has understood them.

This paper is organized as follows: section I summarizes the laws of ona'ah and hafka'at she'arim / hayyei nefesh, to establish the basic characteristics of these laws - but without subjecting them to any critical analysis. Section II similarly summarizes the communal price-controls without criticism. Section III critically evaluates ona'ah, determining that it does not constitute a price-control. Section IV does the same for hafka'at she'arim / hayyei nefesh, concluding that this law is a pricecontrol. Section V summarizes mainstream economic theory concerning price-controls in order to explain why it is so problematic that hafka'at she'arim / hayyei nefesh is a price-control, and why it is undesirable that the community possesses its own power to impose price-controls. Section VI is devoted to criticizing Aaron Levine's defense of the hafka'at she'arim / hayyei nefesh law. As Levine was both a rabbi as well as an academic economist, his own view is particularly noteworthy and deserving of in-depth evaluation. Section VII discusses whether these laws are still binding and authoritative for Jews today, and if so, what resolutions there may be for this dilemma. Section VIII concludes.

\section{Ona'ah and Hayyei Nefesh (Hafka'at She'arim) Summarized ${ }^{2}$}

Shilo defines ona'ah ("wrongdoing" or "harm") as "the act of wronging another by selling him an article for more than its real worth or by purchasing from him an article for less than its real worth" (Shilo and Elon 2008). Similarly, Kleiman (1987: 25) defines ona'ah as "exploitation through price deceit." Ona'ah is based on an interpretation of the verse in Leviticus 25:14, "And if thou sell aught unto thy neighbor, or buy of thy neighbor's hand, ye shall not wrong (tonu) one another." The law of ona'ah prohibits the sale of a good where its price diverges from its "true" market price by one-sixth or more. ${ }^{3}$ Both under- and over-charging are equally prohibited.

Closely related to $o n a^{\prime} a h$ is another law, variously referred to as hafka'at she'arim 
("profiteering") or hayyei nefesh ("life necessities"). Elon (2008) defines hafka'at she'arim as "raising the price of a commodity beyond the accepted level, or that fixed by a competent authority.". Similarly, Warhaftig says (1987: sec. "1") that "a profiteer is one who causes the prices to rise in an artificial manner" and that the halakhah restricts "someone who causes prices to rise without economic justification." Like ona'ah, the law of hafka'at she'arim or hayyei nefesh prohibits sale where the price diverges one-sixth or more from the market price.

One crucial distinction between these two laws is that whereas ona'ah is a Biblical prohibition which may be waived in certain cases by the parties involved, hafka'at she'arim is a Rabbinic enactment (Elon 2008, Warhaftig 1988: s.v. “F. Fraud.”). Counter-intuitively, even though hafka'at she'arim is less authoritative than $o n a^{\prime} a h$ - because it is merely Rabbinic in nature - nevertheless, only ona'ah may we waived with the consent of the two parties, whereas hafka'at she'arim may not be waived - not even with mutual consent. A second distinction is that the two laws apply to different classes of goods. Ona'ah applies to nearly all goods and commodities whatsoever, with the specific exceptions of real estate, slaves, financial instruments, and consecrated objects. By contrast, hafka'at she'arim applies only to essential foodstuffs. ${ }^{4}$ To summarize: ona'ah is a Biblical prohibition which prohibits certain degrees of over- or under-charging on all commodities except real estate, slaves, financial instruments, and consecrated objects, but the parties to the transaction may waive the prohibition with mutual consent. Hafka'at she'arim / hayyei nefesh, by contrast, is a Rabbinic prohibition which applies only to foodstuffs, and this prohibition cannot be waived - not even by the mutual consent of the parties.

Unfortunately, these two distinct laws are so closely related that they are often conflated in the literature, and it is necessary to carefully distinguish between them. ${ }^{5}$ Their close relationship is apparent from Maimonides's organization of Hil. Mekhira ("Laws of Trade"). In Hil. Mekhira chaps. 12 and 13, Maimonides discusses ona'ah. In the first two paragraphs of chap. 14, he turns to hafka'at she'arim. Then in 14:3-11, Maimonides discusses speculation, middlemen, hoarding, communal price-controls, 
and guilds. In the final paragraphs of chap. 14, i.e. par. 12-18, Maimonides returns to the topic of ona'ah. In other words, hafka'at she'arim is sandwiched in between two discussions of ona'ah, showing they are related. Tamari's 1991 presentation is similar: Tamari (1991: 68-72) first discusses hafka'at she'arim, then he turns (1991: 87) to ona'ah, and then he returns to hafka'at she'arim again (1991: 87f.), which this (second) time he confusingly refers to as "cost-related ona'ah." Finally, he concludes with ordinary ona'ah again (1991: 88-91). Elsewhere, Tamari (1987) seems to draw a sharper distinction, separating hafka'at she'arim (1987: 88-96) and ona'ah (1987: 96-100) into two separate discussions. But even then ,Tamari (1987) briefly lumps ona'ah and hafka'at she'arim together into one single statement, saying (1987: 88), "the forms of price control discussed here all refer to basic commodities or their ingredients [i.e., hafka'at she'arim], with investment goods (such as land, slaves, or monetary instruments) excluded [i.e. ona'ah].” Lew (1985) does not clearly distinguish between hafka'at she'arim and ona'ah, shifting seamlessly from discussing the former (Lew 1985: 42) to the latter (Lew 1985: 43) without clearly distinguishing them. Warhaftig (1987) is mostly concerned with hafka'at she'arim while Warhaftig (1988) is mostly concerned with ona'ah, although the latter (Warhaftig 1988) returns to hafka'at she'arim near its conclusion (s.v. "F. Fraud, Profit Limitation, and Unfair Pressure"). Although Kleiman (1987) is predominately concerned with ona'ah, his brief allusion to hafka'at she'arim shows their close relationship: "The rather general, contrasting statement to the effect that profits (from trade?) should not exceed one-sixth (TB BB 90a), seems to have represented an attempt to interpret the ona'ah rules in an all-embracing manner" (Kleiman 1987: 36 n. 23).

With regard to both laws, it is not entirely clear whether whether the official price is publicly announced or whether market participants must research the price for themselves at their own expense. Warhaftig (1988: sec. "Introduction") is equivocal, saying, "The correct price is officially set by the authorities or is the prevailing price in the marketplace." Kleiman notes (1987: 26), "nowhere does the Talmud explicitly mention the reference price from which such a divergence is to be measured," but he concludes (1987: 26) that "the relevant standard was none other than the going market price." Levine 
(2012: 53) agrees with Kleiman, saying, "the reference price for an ona'ah claim is nothing other than the competitive norm." Indeed, the halakhah specifies that the victim of ona'ah has only a limited time to object to the over- or under-charge, according to how long it is estimated it would take him to verify the proper price with an expert (Hil. Mekhira 12:5-11; Warhaftig 1988 s.v. "B. Period of Cancellation"; Kleiman 1987: 26; Tamari 1987: 97f.; Tamari 1991: 78; Weissman 1998: 86-88). This implies that there is no officially posted price which can be easily looked up on a public bulletin, but rather, that the law of ona'ah enforces whatever the market price may happen to be, and that a person must verify for himself what that price actually is (Kleiman 1987: 34 n. 19). So it may be that no fixed price was officially established at all, and instead, it was assumed that the market price would speak for itself.

On the other hand, it appears that a definite price was publicly fixed for hayyei nefesh / hafka'at she'arim, with price inspectors circulating to judge conformance to this official price. Concerning this law, Maimonides (Hil. Mekhira 14:1) declares, "the beit din [i.e. rabbinical court] is obligated to fix prices," which implies a publicly promulgated official price. Likewise, Levine says (2012: 93), "the hayyei nefesh edict required the Jewish court to appoint price commissioners to supervise the marketplace." Therefore, it is possible that prices for the two laws were fixed in two entirely different manners, with the ona'ah price being something market participants must discover for themselves (cf. Hil. Mekhira 12:5-11), but the hafka'at she'arim / hayyei nefesh price being officially dictated and announced (cf. Hil. Mekhira 14:1).

In any case, it is important to remember that these two laws, though similar in many ways, are nevertheless distinct. While they both prohibit sales where the price diverges from the "true" price by more than one-sixth - prohibiting both under- and over-charging - ona'ah is a Biblical prohibition which applies to all goods whatsoever - except for land, slaves, financial instruments, and consecrated objects - and which may be waived with mutual consent. Hayyei nefesh (or hafka'at she'arim) is a merely Rabbinic prohibition which applies only to foodstuffs, and it may not be waived, not even without mutual consent. It is not clear how the "true" price is made known, but it is possible that the 
ona'ah price was left to be discovered by market actors while the hayyei nefesh price was officially promulgated.

\section{Corporate Communal Price-Controls Summarized}

Entirely apart from the beit din (rabbinical court)'s authority to enforce ona'ah and hafka'at she'arim / hayyei nefesh, there is a wholly distinct power resting in the corporate, (relatively) democratic Jewish community (Epstein 1985: i-ii; Warhaftig 1987: s.v. “6. Price Fixing”; Levine 2012: 202) to regulate wages and prices (Hil. Mekhira 14:9, quoted by Levine 2012: 108, 202; Lew 1985: 126; Elon 2008). As Tamari notes (1991: 68), “the people of the city have the right to fix prices (either by majority vote for through their representatives)" (cf. Tamari 1987: 94). Warhaftig (1987 s.v. "6. Price Fixing") quotes Tosefta BM 11:12: "The members of the community may determine prices and measures and wages, and they may enforce their decisions." Similarly, Levine (2012: 108) quotes Maimonides, Hilkhot Mekhira 14:9 (cf. Tamari 1987: 94):

The residents of the city may agree among themselves to fix a price for any article they desire, even for meat and bread, and to stipulate that they will inflict such-and-such penalty upon one who violates the agreement.

Crucially, Levine (2012: 108) comments on Hil. Mekhira 14:9, saying, "communal price-fixing legislation in the hayyei nefesh sector may conflict with the $20 \%$ profit rate the Beit Din [rabbinical court] of the town sets for this sector" in enforcing the original law of hayyei nefesh itself. In other words, the community may impose restrictions on hayyei nefesh (essential foodstuffs) which go beyond the basic $20 \%$ hayyei nefesh law enforced by the rabbinical court. This appears to be a straightforward, unambiguous power to impose wage and price controls even beyond any controls already imposed by the laws of ona'ah and hafka'at she'arim / hayyei nefesh. This power of price-control applies to wages and salaries as well. Thus, Tamari (1987: 149) quotes the Talmud, $B B$ 8b: "The people of the city are 
permitted to regulate weights, prices, and the wages of workers. They also have the power to punish those who do not carry out their regulations."

\section{Ona'ah Evaluated}

In a series of articles, Block $(1986,1990,2002)$ has argued that ona'ah constitutes a form of

price-control, and he has concluded that all of the typical positive economic criticisms of price-controls apply to $o n a^{\prime} a h$. Sharfman (2006) considers $o n a^{\prime} a h$ to constitute a price-control as well. But several scholars have convincingly agued that ona'ah is not meant as a price-control at all. Instead, it is only a measure meant to protect market participants from ignorance and asymmetric information. ${ }^{6}$ While such a law may be open to various objections, it cannot be criticized as a form of price-control.

This interpretation of $o n a^{\prime} a h$ is based on the fact that ona'ah may be waived with the mutual consent of the parties. While it is prohibited for two parties to a transaction to waive the prohibition of ona'ah per se, they may nevertheless effectively do so by disclosing and consenting to the price discrepancy itself. In other words, a stipulation to the effect that "I sell you this on condition that there is no accusation of ona'ah" is invalid, but it is permissible and effective to stipulate, "I am selling you this good worth $\$ 10$ for $\$ 20$ " (Shilo and Elon 2008). The fact that ona'ah can be circumvented by fulldisclosure shows that ona'ah is not meant as a price-control but as a protection against asymmetric information (Kleiman 1987: 29; Weissman 1998: 90; Tamari 1991: 82, 1987: 96f., 1986: 408; Warhaftig 1988 s.v. “Introduction”, s.v. “A. Definition”, s.v. “D. Stipulation and Waiver”).

In addition, Weissman and Kleiman both note the existence of a rejected opinion that the law of ona'ah did not protect merchants, but only consumers, because merchants are experts concerning prices (Kleiman 1987: 28 and Weissman 1998:88f., both quoting TB BM 51a). Although this is not the accepted by the Talmud as the final law (cf. Hil. Mekhira 12:8), Kleiman and Weissman argue that even the rejected opinion reveals a consensus concerning the underlying purpose of the law, viz. to protect the weak and ignorant against exploitation by those with superior knowledge. 
According to this interpretation, the law of $o n a^{\prime} a h$ is not a price-control meant to ban deviations from a given price, but it is merely meant to ensure that market prices are formed under conditions of full information. According to Tamari (1987: 99), "the law of $o n a^{\prime} a h$ would seem to require a public policy requiring full disclosure of the market prices of basic commodities." Later, Tamari suggested (1991: 85) that "the law of ona'ah would ... seem to require communal or government action in order to make information about market prices freely available to all." This does not mean the law is immune to any objections whatsoever, but it does mean that ona'ah is not a price-control (contra Block 1986, $1990,2002) .^{7}$

\section{Hafka'at She'arim / Hayyei Nefesh Evaluated}

By contrast, however, the law of hafka'at she'arim / hayyei nefesh - the price-limitation on foodstuffs - is a price-control. This is because unlike ona'ah, the law of hafka'at she'arim cannot be waived, not even with the mutual consent of the two parties. As Warhaftig says (1988 s.v. "F. Fraud...”), "Profit limitation is an obligation not subject to change through stipulation or waiver, unlike ona'ah." And in the words of Maimonides (Mishneh Torah, Hilkhot Mekhira 14:1, trans. Levine 2012: 102):

We have already explained that he who does business on trust (nosei be-emunah) and says "I make so much and so much profit" is not subject to the law of overreaching (ona'ah), and even if he says "I bought this article for a sela and am selling it to you for ten," it is legitimate. Nevertheless, the court is obligated to regulate prices [lifsok hashe'arim] and appoint officers of the law, so that people at large will not be able to reap whatever profit they desire, but should earn a profit of only one-sixth [i.e. 20\%].

Maimonides immediately proceeds to clarify that this only applies to essential foodstuffs (Hil. Mekhira 14:2). According to Levine (2012: 104),

Maimonides conveys the notion that the price ceiling for hayyei nefesh items [i.e. essential foodstuffs covered by hafka'at she'arim] is absolute and precludes the 
possibility for $\mathrm{S}$ and $\mathrm{B}$ to strike a deal that effectively allows $\mathrm{S}$ to earn a profit in excess of $20 \%$.

Whereas is permitted to commit ona'ah as long as one specifies the precise extent of the pricediscrepancy, in the specific case of foodstuffs, the rabbinical courts are required to enforce the onesixth law of hafka'at she'arim / hayyei nefesh even when the market participants themselves consent to waive it.

Quoting the Medieval commentator Rabbi Menahem ha-Meiri, Elon (2008) summarizes the distinction between ona'ah and hafka'at she'arim / hayyei nefesh as follows: whereas ona'ah is a Torah prohibition which applies to all goods (except land, slaves, bills, and consecrated property),

The law of profiteering [i.e. hafka'at she'arim / hayyei nefesh] on the other hand has its source in rabbinic enactment designed to prohibit the setting of prices in excess of the customarily accepted ones, even if the purchaser is aware of and agrees to the inflated price; “... even when he [the seller] says 'it cost me one sela and I want to earn two on it,' he has not transgressed the law of $o n a^{\prime}$ ah but he is prohibited by rabbinic enactment [of hafka'at she'arim / hayyei nefesh] from making a profit of more than one-sixth in essential commodities" (Beit ha-Behirah, BM 51b).

Because hafka'at she'arim / hayyei nefesh cannot be waived, it - unlike ona'ah - definitely constitutes a price-control. Whereas $o n a^{\prime} a h$ is designed only to protect against information asymmetry, hafka'at she'arim / hayyei nefesh imposes an inescapable control on prices. Indeed, Maimonides speaks explicitly of "appoint[ing] officers" because "the court is obligated to regulate prices" (cf. Lew 1985: 42). Thus, Tamari concludes (1991: 68; cf. 1987: 94, 1991: 70) that "The obligation of the beit din [rabbinical court] to appoint officials who, in addition to their role as supervisors of weights and measures, will control prices of basic goods is recognized by all the codes."

Moreover, as we saw earlier, the corporate, (relatively) democratic Jewish community possesses the power to regulate wages and prices independently of the beit din (rabbinical court)'s enforcement of 
the laws of ona'ah and hafka'at she'arim / hayyei nefesh. In short, while ona'ah is not a price-control, hafka'at she'arim / hayyei nefesh certainly is one. And the community's power to impose wage and price controls is exactly that.

\section{The Self-Defeating Nature of Price-Controls ${ }^{8}$}

As we saw, hafka'at she'arim / hayyei nefesh specifically fixes the prices of essential foodstuffs, suggesting that the law is meant to ensure a stable and reliable food supply especially for the poorest and weakest of society - particularly in times of famines and other disasters. Indeed, the hafka'at she'arim law does not impose price controls on luxuries which are not essential for the maintenance of life. According to Goldstein (2006: 447),

Jewish law ... intervenes to help the poor. For example, price controls are imposed on essential goods to make them affordable to the poor. Such an intervention benefits people ... The poor can thus benefit, together with others.

Similarly, discussing essential foodstuffs, Lew argues (1985: 184f.):

The Rabbis regarded the raising of prices above their actual value as a serious threat to the economic welfare of the public.... It is obvious that these rules were designed to control prices which would otherwise be higher and bear harshly upon the poor. ... In any event care was taken to prevent unscrupulous merchants from taking advantage of the poor.

Similarly, Epstein states (1962: iv), "the prices were fixed not at individual discretion, but were corporately determined with a view to safeguarding the standards of life of the consumers." Likewise, Warhaftig concludes (1987 s.v. "C. Summation and Application”), "there exists a measure of intervention and supervision designed to ensure that the lower economic classes will be able to purchase essential items at affordable prices.” According to Tamari (1987: 91), "The basic concern behind these injunctions ... was the welfare of the average consumer.” And finally, Levine (2012: 93) 
states that the purpose of these laws is "to allow consumers to achieve subsistence without undue hardship."

But good intentions do not ensure good consequences. The question is, are the means appropriate to the ends? Paradoxically, adopting price controls for necessities and allowing a free market for luxuries, will produce the very opposite results than what was intended. That is, price controls are actually an impediment to continued supply of a good, while economic freedom is the best guarantee that shortages will not arise. In fact, price-controls will accomplish the very opposite of what is intended, and tragically so. Establishing and enforcing price-controls in foodstuffs while allowing a free-market in luxuries will paradoxically guarantee a plentiful supply of luxuries while essentials will dwindle into insufficiency, exactly the situation that was sought to be avoided. One may visit contemporary (2016) Venezuela for an illustration.

The problem with all price controls is that prices - i.e. rates of exchange between two goods, or one good and money - have an essential role to play in an economy. Suppose that for some reason there is a surplus of mechanics and a shortage of electricians. The way the price system handles such a challenge is simplicity itself. The wage of mechanics falls, and that of electricians rises. This leads people who have attained or can attain both skills to switch from the former to the latter. Over the longterm, students just entering trade school will tend to decide to study to become electricians instead of mechanics, on account of the higher wages in the former. Similarly, if there is a great demand for cabbage and small demand for broccoli relative to supply, the price of the former will rise and that of the latter, fall. This will again tend to lead entrepreneurs, as if by an "invisible hand," to tailor their offerings to the wishes of consumers. The higher price of cabbage will call forth more of this vegetable, and the lower price of broccoli will reduce incentives to bring that product to market, at least on the part of all those who attempt to maximize their returns. As for those who ignore these market signals, all other things being equal they will tend towards bankruptcy. It is in this way that a decentralized market can produce a spontaneous order, functioning in a rational manner without any central direction 
at all. This may not seem important to some, but it has great importance for our welfare; no less than the feeding, clothing and sheltering of the persons of humanity is at stake.

Price-controls, of course, prohibit the movement of prices without government permission. But in the time it takes for bureaucrats to discern the relative disequilibrium of mechanics and electricians, or of cabbage and broccoli - to say nothing of the hundreds of thousands of other items in a modern economy - there is no possibility of rectifying matters sufficiently so as to attain a smoothly functioning economy. In this regard hafka'at she'arim / hayyei nefesh would not be a total disaster. Instead of preventing such price changes, it merely retards them. This Talmudic law allows prices to fluctuate plus or minus $20 \%$ from the official market price. If resources can be fully allocated by, say, a price change of only $10 \%$, then hafka'at she'arim will have no explicit deleterious effect on the economy. But if full resource allocation is possible only with a price change of greater than $20 \%$, say of $30 \%$, then hafka'at she'arim will restrict the change to $20 \%$ and prohibit the most efficient use of society's resources and will therefore restrict the potential for consumer want-satisfaction.

Profits are the means by which consumers signal to the producers and suppliers their priorities and preferences. Thus, profit-and-loss signals provide essential feedback in the market process (Coyne and Coyne 2015b: 9-12). If people come to fear they may not have enough eggs and cheese for their growing children, profits in egg and cheese production will rise. This will draw increasing investments into this industry - for investors seek profit opportunities - and draw investments away from competing industries. The increased investment will spur additional production in eggs and cheese, and production will be reduced in competing industries for which demand is less urgent and from which investment was withdrawn. But if the government artificially limits profits, this process will be frustrated according to the extent of the intervention. Price-controls serve like a perverse warning sign to the entrepreneur and investor. In the absence of controls, he had looked upon all investment opportunities on an equal basis, focusing on the items which people demonstrated were most important to them, so as to maximize his own returns by serving the customers to their own satisfaction. But now, 
with price-controls and profit limitations, he will tend to avoid these options. There will be economic perversity as a consequence. Whereas in a free-market, resources flowed away from industries producing less urgently-required resources and towards industries producing essentials, once pricecontrols are imposed on essentials, the very opposite will occur. Resources will flow away from industries producing necessities, where they are most needed, and towards luxuries, where they are not. Given the presumed goal of the Rabbis, the mandate to impose regulation on necessities and to allow freedom for luxuries is the very opposite of what will best serve the community. Given the Rabbis' goals, then if we absolutely must have government interference in the economy, it would be far better to control extravagant items and to leave essentials strictly alone. Were price-controls to be imposed on luxuries and a free-market allowed in essentials, then investment would flow away from luxuries and towards essentials, and the goals of the Rabbis would be better accomplished.

One might object that all this is true only in the long-term, when production can adjust to new prices. Perhaps in the short-term, price-controls are actually beneficial for assisting the poor weather the adverse conditions. In the short-term, supply is relatively fixed - the supply curve is a vertical line and so supply cannot adjust to prices anyway. However, price-controls are self-defeating in the shortterm as well, due to their effect on demand. Whereas the quantity supplied will increase in the longterm in response to an increase in price, it is equally true that quantity demanded will decrease in the short-term in response to that same increase in price. In other words, prices serve to ration scarce supplies in the short-term by modulating demand. For example, suppose a famine has struck and there is only a small quantity of grain left. If the price is allowed to remain at its customary level, then consumers will continue to consume the same quantity of grain as they have before, unless strict rationing measures are imposed, such as establishing quotas or requiring rationing coupons in addition to money. Furthermore, the first people to arrive at the marketplace will be in a privileged position to purchase all the available grain, leaving nothing for late-comers. Furthermore, because people are interested in buying more grain at below-market prices than can be accommodated, sellers of grain 
know they may indulge their own preferences and biases, selling favoritistically. For example, if people wish to buy more grain than is available, the seller will be in a position to refuse to sell to religious or ethnic minorities without sacrificing any profits. In other words, below-market prices lead to queues, and queues in turn tend to favor early-comers at the expense of late-comers, or else allow sellers to indulge their biases and even bigotry. But if the price of grain is allowed to rise in response to the shortage induced by the famine, then consumers will consume less grain in the short-term, stretching out the limited supply over a longer period until enough time has passed that supply can increase in response to the higher price. Queues will disappear, and thus consumers will be in a more equitable position relative to one another.

Therefore, not only are price-controls disastrous for their effect in reducing quantity supplied, but they cause equal damage in increasing quantity demanded, compared to the lesser quantity which would be demanded if the price were allowed to increase to its new market level. Price-controls established in times of privation and famine thus serve to harm the very people they are intended to help in not one but two ways, like Marshall's analogy of the two blades of a scissors: when supplies are short, price-controls reduce the quantity supplied and increase the quantity demanded relative to what they would be in a free-market, thus making the famine or disaster doubly insufferable. The consequences of price-controls, therefore, are never what they aim to be, but instead, they produce queues (Coyne and Coyne 2015b: 19), black markets (Coyne and Coyne 2015b: 20), and product quality deterioration (Coyne and Coyne 2015b: 20). Price-controls even promote discrimination (Coyne and Coyne 2015b: 20, Levine 2012: 193). Ordinarily, a person can indulge in their racist or sexist - or otherwise discriminatory - preferences only by suffering a reduction to their profits. For example, if markets are clearing and supply equals demand, a person cannot refuse to sell to ethnic minorities unless they are willing to lose a substantial portion of their customer base. In fact, railroad firms lobbied against Jim Crow for precisely this reason (Gorman 2008 quoting Roback 1986). But when minimum prices cause quantity demanded to exceed quantity supplied, discriminators can afford to 
indulge their preferences. If there are already more customers than there are supplies to sell them, then the seller loses little by deciding to sell only to favored ethnicities. Thus, price-controls have several negative consequences aside from their simple promotion of surpluses and shortages.

\section{Aaron Levine's Interpretation}

According to Aaron Levine, however, hafka'at she'arim is not a price-control at all. Being both a rabbi as well as an academic economist, Levine was specially situated to appeciate the significance of the hafka'at she'arim law, and he understood how damaging it would be to the Jewish religion if hafka'at she'arim suffered from the typical failures of price controls. Therefore, he was forced to argue that hafka'at she'arim is different from other price controls. We devote this section to closely examining Levine's defense of the hafka'at she'arim law. ${ }^{9}$ We shall conclude that his defense is unconvincing, and that hafka'at she'arim remains a harmful price-control after all.

According to an early statement by Levine (1985a: 424),

Raising price on the basis of an upward shift of the demand curve is regarded in Jewish law as unethical when the shift is rooted in a changed circumstance, e.g. war, which makes the consumer's need for the product desperate. Similarly unethical is the raising of a price when the shift is due to an artificially created need by dint of religious law.

Unfortunately, Levine has confused a rightward (or upward) shift of the demand curve with a leftward (or upward) shift of the supply curve. Warfare does not increase demand but rather it decreases supply. It is not that people wish to eat more food in wartime than they used to consume in peacetime; it is rather that war makes food harder to come by at any given price. Invading armies of the time lacked supply lines, and they sustained themselves from the fields. They may have also burned whatever they could not consume themselves. Therefore, the supply of all crops at a given price would have shifted left, becoming more scarce. Now, it is true that demand will shift right (towards urgency) as consumers speculatively anticipate a future rise in prices due to the supply shock. In other words, consumers will 
be willing to spend more for a given quantity of food in the present because they anticipate that prices will rise in the future because of the war. But this rightward shift in demand is in response to the anticipated leftward shift in supply. Therefore, the principal effect of warfare is a leftward supply shock, and the rightward shift in demand is merely a secondary response to that supply shock. Levine has somehow neglected the primary shift in supply and focused on the secondary shift in demand.

In any case, however, Levine has failed to realize that a price-control in this situation will be self-defeating and harm the very people it is meant to help. When warfare has caused a decrease in the supply of essential goods, prices must be allowed to increase for two reasons: first, to call forth an increase in supply, and second, to reduce quantity demanded and allocate the limited supply that remains. If, on the contrary, a price-control is imposed, then there will be no incentive for suppliers to alleviate the privation and consumers will consume too much and fail to economize the limited supply. Similarly, it is economically irrelevant whether a shift in consumer demand is artificially created by religious law; regardless of the cause of the shift, any restriction on the free movement of prices will create negative consequences which harm the very people whom the law intends to help. Thus, Levine is completely wrong to argue that a price-control in a situation of scarcity or shortage "would not really impose much of a problem in terms of resource allocation" (1985b: 447).

In his latest writing (2012), Levine's argument is far more sophisticated. Levine notes from the outset of his analysis that price-controls are self-defeating $(2012: 22,93-95,110)$. He recognizes that prices serve as signals (Levine 2012: 93) directing the allocation of resources (Levine 2012: 94), and that profits serve the same function as well (Levine 2012: 94). Price-controls will generally result in shortages, black markets, and the necessity for rationing (Levine 2012: 94). Furthermore, price-controls discourage new entry by alternate suppliers (Levine 2012: 94). Concerning wages in particular, Levine recognizes that where minimum wages or mandatory union membership drive wages above the marketclearing rate, employers will reduce their demand for employees, producing permanent unemployment (Levine 2012: 191-193, 209; cf. Siebert 2015). Ironically, then, the minimum wage hurts the very 
people it is meant to meant to help, producing self-defeating consequences (Levine 2012: 191-193, 209). For this reason and others as well, Aaron Levine argues that Jewish law would reject any form of minimum wage (Levine 2012: 191-210). Recognizing that the minimum wage must be rejected along with all other price-controls, he attempts to show that the profit-limitation of hafka'at she'arim is not a price-control at all.

In Levine's interpretation (2012: 106), "the rabbis set the price ceiling above the equilibrium price" (cf. Levine 2012: 107, 110, 111). But the price ceiling is not the price which the rabbis enforce. As Levine says $(2012: 107,111),{ }^{10}$ "Because the price ceiling is a matter of public knowledge, some may, however, erroneously regard it as a mandated price." In fact, sellers are not bound by the rabbinic price ceiling but rather by the equilibrium status quo market price. "It is the role of these supervisors to survey the marketplace and make sure that no one sells above the competitive norm" (Levine 2012: 107; cf. 2012: 111). If the sellers are bound, not by the rabbinic price ceiling but rather by the competitive market price, then what function does the rabbinic price ceiling serve? Levine answers that "the usefulness of setting a price ceiling is that it signals the rabbis when remedial measures should be put in place ... [including] a rationing system" (Levine 2012: 107, 111), ${ }^{11}$ to be implemented after the market price has increased such that "the price ceiling becomes the competitive norm" (Levine 2012: 107, 111). ${ }^{12}$ In other words, sellers are bound by the competitive market price itself, and the price commissioners of the court enforce that market price, not the price ceiling. The function of the price ceiling is only to serve as a signal. Once the market price increases to the point that it equals or exceeds the price ceiling, then further interventions become warranted, including non-price rationing (cf. Levine 1985a: 423). For Levine, the market price is to be allowed to freely fluctuate, but if supply shocks (Levine 2012: 107) cause the competitive market rate to increase to the point that it reaches the official price ceiling, this will serve as a signal for the beit din (rabbinical court) to institute non-market rationing schemes. Furthermore, this mechanism is to be coupled with the communal institution of wage and price controls (Levine 2012: 108, 111), which may conflict with and supersede the hayyei 
nefesh ordinance (Levine 2012: 108). The purpose of these controls is to eliminate economic rents and profits (1985a: 423; 1985b: 448f.; 2012: 109, 112).

But there are a few problems with Levine's interpretation: first, there is still a system of pricecontrols, only the price which is enforced is not the official price declared by the beit din, but rather the alleged competitive market rate. In other words, there is a sort of terminological dispute about what to call the price that is enforced, but there is still some price that is enforced. The entire purpose of Levine's interpretation was to deny that the Talmud imposed price-controls, for he admitted that pricecontrols are self-defeating (Levine 2012: 22, 93-95, 110). But after all his efforts, his interpretation still results in there being a price-control, only the price which the courts enforce is not the official price promulgated by the courts, but rather, the courts enforce what they perceive to be the status quo market price. Either way, a price-control is still being enforced. A price-control is still a price-control regardless of whether the price that is enforced is an officially promulgated price or whether it is the preexisting status quo market price from which future deviations are prohibited. If deviations from the status quo market price are prohibited, then this still constitutes a price-control with all its attendant negative effects. If market conditions change such that the equilibrium market-clearing price changes but the status quo market price continues to be enforced, then the market will be unable to clear, and there will be economic misallocations and dislocations. Furthermore, in his interpretation, once the market price rises to equal the official price, at that point, the court is supposed to institute non-pricerationing, which means there is still a price-control. Moreover, Levine says that all this is to be coupled with communal wage and price controls. So all Levine has done is to replace one form of price-control with another.

Second, it is difficult to understand how the market price could ever rise to meet the official price-ceiling if the commissioners punish every deviation from the market price. Levine is remarkably unaware of the contradiction between his statements. On the one hand, he says, "It is the role of these supervisors to survey the marketplace and make sure that no one sells above the competitive norm" 
(Levine 2012: 107; cf. 2012: 111). On the other hand, he argues for remedial measures to be implemented after the market price has increased such that "the price ceiling becomes the competitive norm" (Levine 2012: 107, 111). But how are prices to rise if sellers are bound by the status quo market prices? ${ }^{13}$ As we noted, enforcement of the status quo market price is still a price-control. Suppose the market price is today $\$ 10$ and the official price-ceiling is \$20 (following Levine's interpretation that the two differ). When the market price rises to $\$ 20$, Levine would say, this would serve as a signal to the court to take remedial action, including rationing (Levine 2012: 107). ${ }^{14}$ But how is the market price to rise from $\$ 10$ to $\$ 20$ if the first merchant to charge $\$ 12$ (deviating more than one-sixth from $\$ 10$ ) is immediately punished and forced to sell at $\$ 11$ (within one-sixth)? If every significant deviation from the market price is immediately prevented, how will the market price ever change?

Perhaps Levine assumes the price will change only gradually, from $\$ 10$ to $\$ 11$ to $\$ 12$, etc., $\$ 1$ at a time, until it finally reaches $\$ 20$, instead of going straight from $\$ 10$ to $\$ 20$. Starting with a price of $\$ 10$, then one may charge $\$ 11.67$, i.e. $1 / 6$ more than $\$ 10$. Then, when all of one's competitors begin to charge $\$ 11.67$ as well, so that this new price becomes the general price, one may charge $1 / 6$ more than that, or $\$ 13.60$. This process will continue until one finally reaches $\$ 20$, the efficient market-clearing price which was desired all along. But if an increase from $\$ 10$ to $\$ 20$ is necessary to achieve marketclearing equilibrium, then the last thing we want is to delay that transition by forcing it to be gradual, compelling the price-transition to proceed by proportions of $1 / 6$. The faster the transition is made, the less painful it will be and the fewer economic disruptions and dislocations it will cause. If the current market price is $\$ 10$ and some alert entrepreneur realizes that the market will clear only at $\$ 20$, then we want him to be able to immediately charge $\$ 20$. We do not want him to have to first charge $\$ 11.67$, then wait until all his competitors charge $\$ 11.67$ too (so that $\$ 11.67$ becomes the new market price), and then charge $\$ 13.60$, etc., repeating this tedious process until $\$ 20$. There appears to be no theoretical economic reason why such a gradual transition would be desirable. At the very least, the burden of proof lies with Levine to justify such gradualism. 
Nor did Levine ever indicate that he had such a gradual transition in mind in his statement that the price-level would be permitted to change even as deviations from it were simultaneously prohibited. Instead, it appears more likely that Levine was not even aware of the contradiction in his statements. Levine apparently relied on a perfectly competitive, static-equilibrium conception of price theory, whereby the general market rate of prices changes according to the actions of a mythical Walrasian auctioneer without any individual market participant ever having changed his own prices. According to the theory of perfect competition, every market participant is a price-taker rather than a price-maker, and no individual market participant is responsible for changing the general price-level. But then who does change the price-level? According to the static conception, the price changes itself without any human input. But according to theory of the market as a "process" (Kirzner 1997), the general price-level can change only as a result of individual market participants changing their prices, one-by-one. The general price level will change from $\$ 10$ to $\$ 20$ when merchants individually change the prices they charge, in response to individually changing perceptions of relative supply and demand by different market participants.

If the Talmud - like Levine - assumed a static-equilibrium model of a general price-level that changes without any individual market participants changing their prices, then hafka'at she'arim would definitely be a price-control - contrary to Levine's interpretation - for the court commissioners would have to ban every deviation from the market price by individual merchants and thus prevent the price from ever changing. The market would be allowed to change its own prices, but no human agency would be permitted to do this. Only the mythical Walrasian auctioneer would be permitted to alter prices, and any individual who attempted to preempt the market by changing his own prices first, would be punished by the court's market inspectors. Levine's attempt to show that hafka'at she'arim is not a price-control will have failed. At best, prices would be permitted to change only gradually, in the manner which we have indicated, from $\$ 10$ to $\$ 11.67$ to $\$ 13.60$, but without passing directly from $\$ 10$ to the market-clearing rate of $\$ 20$. Interpreted in this way, hafka'at she'arim would not constitute a pure 
price-control, but it would nevertheless put a brake on economic adjustments and unnecessarily prolong the agony of economic disequilibrium.

But if the Talmud understood the market as a "process" (Kirzner), then the Talmud would have understood that the general price-level changes if and only if individual merchants change their prices. In that case, allowing the general price-level to change necessarily presumes that merchants have freedom to charge whatever prices they wish. If this is the case, then the Talmud could not have intended what Levine argues it did, namely that the commissioners were to ban individual merchants from deviating from the market price at the same time that the general price-level was to be allowed to somehow fluctuate until it reached the official price. Either the Talmud assumed that the market is a dynamic process, and Levine's interpretation of the Talmud is untenable; or else the Talmud assumed static-equilibrium, and hafka'at she'arim is indeed a price-control, contrary to Levine's claim. Or it is possible that the purpose of the law was to prolong economic adjustment by forcing price changes to be unnecessarily gradual and step-wise, in which case Levine has failed once again to prove hafka'at she'arim is not a price-control. In any case, it is not clear what Levine intends, and every interpretation reduces to some sort of price-control or another. Furthermore, Levine ultimately appeals to the community to impose wage and price controls outside the scope of hafka'at she'arim, so his attempt to defend the Talmud from the claim that it permits price-controls, must necessarily fail.

Interestingly, Levine assumes that the law of hafka'at she'arim is no longer legally binding, but he never specifies the legal mechanism by which this law has been annulled. He states (2012: 109, $112):{ }^{15}$

What survives is not the $20 \%$ figure per se. This figure made sense only for the marketplace and economic conditions that existed at the time of the enactment of the ordinance. The general objection to "excessive profits" for those who deal in essential products should, however, remain. What should be substituted for the $20 \%$ figure today is the notion that the ideal is to craft government tax and regulatory policy to eliminate 
economic rents in the hayyei nefesh [essential foodstuffs] sector. In other words, the goal should be to prevent profits in this sector from exceeding opportunity cost earnings. ${ }^{16}$ What Levine means by "opportunity cost earnings" is that no merchant should be allowed to earn more selling foodstuffs than he could earn in any alternative employment or occupation. In other words, the merchant should be allowed to earn just enough to convince him to remain a merchant, but not more. Unfortunately, Levine's scheme of taxing profits above opportunity costs to eliminate rents is not any better than the original price-control which he sought to avoid. As we showed earlier, profits and losses are essential signals to investors and producers. Profits motivate new entry while losses inspire exit. Taxing excess profits would therefore deter new entry, as Levine himself says (2012: 94). For example, if a famine has struck a land and the price of food has skyrocketed, the excess profits will encourage foreign suppliers to divert their food supply from their own domestic market where profits are normal, to the famine-stricken market where profits are excess. If suppliers are forbidden to earn higher profits in the famine-stricken market than in their own local market, then they will have no incentive to export supplies to alleviate the famine. Why export food just so you can earn the same return as if you had sold it locally? Levine's scheme of taxing excess profits would thus disrupt the price-mechanism and create disorder in the market, just like any other price-control. All prices communicate essential information and price-signals alone efficiently promote economic coordination. There is no scientific way to declare that a profit is excessive or detrimental to the consumer. Profit-and-loss signals provide feedback which is essential to the healthy and effective operation of the market process (Coyne and Coyne 2015b: 9-12).

Levine's eror is especially puzzling because he himself correctly pointed out how essential profits are for coordination and signaling (Levine 2012: 94) and that price-controls are therefore selfdefeating (Levine 2012: 110). Hence, it is not clear why Levine considers it desirable to eliminate profits. Perhaps it is because in Neoclassical static-equilibrium analysis, "above-normal profit is taken as an indicator of monopoly, and evidence of an inefficient allocation of resources" (Holcombe 2014: 
388; cf. DiLorenzo 1988: 321f. and Pasour 1987: 124-126). But as Holcombe has pointed out (2014: $390,400)$,

profit is a sign of increased efficiency in the allocation of resources, not a sign of inefficiency. Consider this even within a comparative static framework. If one starts with the situation in which all markets are in equilibrium and there are no economic profits, and then an entrepreneur introduces an innovation into the market that generates economic profits, that profit will be the result of either an innovation that lowers the cost of production of the entrepreneur's output, or produces a good or service that purchasers value more than the alternatives previously available. Either way, the profit is an indication that resources are being allocated more efficiently than before, and welfare has increased. ... Above-normal profits indicate a welfare loss within a static framework, because using competitive equilibrium as a benchmark for efficiency, the firm making above-normal profit is doing so by producing an inefficiently low quantity to maintain that profit. However, when profit is the result of innovation, a competitive industry is the wrong benchmark, because the output would not have been produced were it not for the lure of future profit.

In general, profits are a signal and an incentive for entrepreneurs to cut costs and introduce innovations which will benefit consumers (Holcombe 2014, Coyne and Coyne 2015b: 9-12.). Therefore, eliminating profits will remove the incentive for innovation and cost-cutting. Hence, it is not clear why we would want to follow Levine in eliminating economic rents and taxing excess profits. ${ }^{17}$ Perhaps what Levine meant is that excess profits should be taxed only in the case of monopoly (cf. Levine 2012: 95) but not in the case of above-normal returns for successful entrepreneurship and innovation. If so, then this would bring us into the field of the theory of monopoly, which is beyond this article's scope. ${ }^{18}$ In any case, while Levine recognizes that price-controls are self-defeating, his attempts to show that hafka'at she'arim / hayyei nefesh does not constitute a price-control fails because every one 
of his interpretations ultimately reduces to some form of price-control or another.

Levine's treatment of the minimum wage is similarly disappointing, for once again, he uncritically endorses the community's dangerous power to impose arbitrary wage and price controls. As we saw earlier, Levine rejects the minimum wage and mandatory union membership because they will cause permanent unemployment, hurting the very people they are meant to help (2012: 191-210). Instead, Levine argues that the democratic community ought to exercise its ability to regulate wages and prices in order to judge certain contracts as unconscionable - for example, a private employment contract stipulating that the employee is forbidden to seek additional employment on the side even though the employee's wage is insufficient to live on (Levine 2012: 202-204). Thus, Levine recognizes and endorses the community's power to arbitrarily regulate prices and wages, but he trusts that the community will exercise this power only in ways which he as an economist approves.

Now, let us suppose for the sake of argument that such a contract nullification would indeed have no negative effects. Unfortunately, Levine nowhere indicates what would constitutionally constrain the democratic community to use its power only in such economically responsible ways. It is not enough to argue that the community ought to limit the exercise of its own power. Such a mere warning without institutional safeguards will turn out to be impotent. As Lord Acton famously declared (1887), "All power tends to corrupt; absolute power corrupts absolutely.” Therefore, Thomas Jefferson declared (1798), "In questions of powers, then, let no more be heard of confidence in man, but bind him down from mischief by the chains of the Constitution.” And as James Madison warned (1788), "In framing a government which is to be administered by men over men, the great difficulty lies in this: you must first enable the government to control the governed; and in the next place oblige it to control itself."

Unfortunately, Levine gives no indication of any constitutional restrictions on the democratic community's power to impose wage-controls. He wishes for the community to use its power responsibly only to nullify unconscionable contracts, but he gives no reason to believe that the 
community, having been granted this unlimited power, will indeed exercise it responsibly. In reality, voters are not only "rationally ignorant," but they are often "rationally irrational," voting “expressively" based on what makes them feel good or what satisfies their consciences (Caplan 2007, Pennington 2011: 65-69). It is easy to imagine the electorate of the Jewish community voting to impose wage-controls, idealistically - but wrongly - believing that this will improve the welfare of the poor. Consider Epstein's (1962: vi) endorsement of the community's power to regulate wages:

Property did not give owners the right to hire workers on their own terms. The wages were fixed with a view to safeguarding the workers' standard of life by the authorities, who drew up regulations as to the wages and hours of labour and other rights of the workers.

Epstein sees nothing objectionable about arbitrary wage controls. Levine, recognizing the existence of this power, wishes for it to be used only to nullify unconscionable contracts, not to arbitrarily regulate wages as Epstein wants. But we are given no assurance that the Jewish community will always heed Levine rather than Epstein in its exercise of its absolute power. Thus, Levine recognizes that the power to control wages control is harmful and dangerous unless used only to nullify unconscionable contracts, but he recognizes no institutional safeguards against the abuse of democratic power to control all wages whatsoever. He endorses the community's unlimited power to control wages, naively trusting that this power will not be used inconsistently with the counself of academic economists. But a robust political system cannot trust in blind faith that the right people will be in power. Robust political economy means ensuring tolerably good results even under adverse, sub-optimal conditions (Pennington 2011). An unconstrained democratic power to impose wage and price-controls fails to satisfy this criterion. Perhaps a corollary of Murphy's Law is in order: if power - even democratic power - can be abused, it will be.

VII. Are these Laws Still in Force? Possible Resolutions. 
We have now seen that while ona'ah is not a price-control, enforcement of hafka'at she'arim / hayyei nefesh is a self-defeating price-control. Likewise, the community's power to democratically impose wage and price controls would be economically self-defeating as well. The question is, what if anything can be done about these issues? According to several authors, the prohibition of ona'ah is no longer legally binding because in a modern, free economy, there is no such thing as the "true" price of a good anymore (Shilo and Elon 2008; Warhaftig 1988 s.v. “G. Contemporary Application”, end of section“C. Exceptions”). Perhaps the same applies to the law of hafka'at she'arim / hayyei nefesh as well, which similarly prohibits deviations of $1 / 6$ from the price. If ona'ah cannot be enforced because there is no such thing as a "true" price from which deviations of $1 / 6$ are prohibited, then the same ought to be true of hafka'at she'arim / hayyei nefesh. Indeed, we saw that Levine states $(2012: 109,112)$ that "What survives is not the $20 \%$ figure per se. This figure made sense only for the marketplace and economic conditions that existed at the time of the enactment of the ordinance." And according to Warhaftig (1988: end of sec. “C. Exceptions”), “in most cases today it is impossible to establish a market price." Furthermore, he states (ibid. s.v. "G. Contemporary Applications") that "in a completely free market, where every merchant has his own price[, $t$ ]here is is no market price, and therefore no ona'ah." Elon makes the same argument (Shilo and Elon 2008). And if the nonexistence of a "true" price nullifies the prohibition of ona'ah, the same ought to be true of hafka'at she'arim / hayyei nefesh. This analogy is made easier by the fact that whereas ona'ah is a Torah-prohibition, hafka'at she'arim is merely Rabbinic (Elon 2008, Warhaftig 1988: s.v. “F. Fraud...”). Rabbinic laws are considered to carry less authority than Torah laws, and so nullifying a Rabbinic law is easier than nullifying a Torah law.

Furthermore, Elon (2008) states, “the rules concerning profiteering were only to take effect if imposed as measures of general application to all vendors, otherwise the individual could not be obliged to adhere to the permitted maximum rate of profit." Similarly, according to Warhaftig (1987: end of sec. "4. Profit Limitation"), "a merchant is obligated to abide by this law only if there is a supervisory mechanism to insure that all merchants conform to its provisions. If, however, the market 
is unregulated one does not have to sell cheaper than others." The idea seems to be that a merchant does not have to hamstring himself by abiding by these laws if his competitors are not. If any part of the market is unregulated, then the merchants in the regulated sector are not obligated to abide by the regulations either, lest they face competitive disadvantage. But in this era of globalization, the relevant market seems to be the world market. Therefore, it would not be enough for the State of Israel (Medinat Yisrael) to enforce hafka'at she'arim in the land of Israel (Eretz Yisrael), because the inhabitants of the rest of the world remain unregulated. If these laws were enforced in Israel, then domestic Israeli commerce would face international competitive disadvantage. And as long as the rest of the world is not regulated by the Talmud's laws, then the market per se is not regulated by the Talmud either. Since the relevant market today is the world market, then the whole world must be regulated by the Talmud's laws in order for the Talmud's economic regulations to be binding for Jews in Israel. If the non-Jewish world does not enforce these halakhic regulations, then apparently, no Jew is obligated to abide by them either. In an era of global trade, domestic interventionist regulations are liable to backfire even worse than in a closed domestic economy. And becaise tariffs and other forms of protectionism lead to monopoly and reduced consumer welfare, such regulations ought not be imposed in the first place. Assuming the State of Israel permits international free-trade as it ought to, then the State of Israel and the religious Jewish courts (batei din) ought not enforce the Talmud's regulations, lest Israeli merchants face competitive disadvantage from foreigners who are not so restricted.

However, none of this would help us account for communally-imposed price-controls. Because these laws have no reference to the $1 / 6$ fraction with respect to the "true" price of a good, we cannot say that these laws are no longer binding on account of the nonexistence of such a price. Luckily, the corporate community's power to impose wage and price controls appears to be moribund and in desuetude, simply because modern Jewish communities are not constituted as they once were, as politically independent, sovereign bodies (Menachem Friedman 1982, 1986, 1993, 2004; cf. Tamari 1991: 15). Today, the locales where Orthodox Jews live tend to have a multiplicity of competing rabbis 
and rabbinical courts, and none of them has the sort of territorial monopoly on the legitimate use of force which would be necessary to impose wage and price controls. Furthermore, the communities are so localized that it is likely that any attempt to impose the controls would become a self-evident failure. Imagine, for example, a synagogue in New York City attempting to dictate that every one of its congregants must pay half the going rate for food and must work for at least double the going rate of wages. This synagogue's members would immediately find themselves unable to purchase food or find employment in a competitive marketplace. Any Orthodox Jew who told the local supermarket that he is only allowed to pay half the going rate for food, or who told his employer that he must be paid double the going wage-rate for his occupation, would be laughed at, and it is unlikely that any synagogue would attempt to enforce such a decree. If the synagogue tried, the congregants would probably all vote with their feet (Tiebout sorting) and begin attending a competing synagogue which allowed them to purchase food and to find employment at the going market rates. Therefore, jurisdictional competition in the modern world has probably nullified the communal price-controls. Nevertheless, we should admit that once upon a time, when the Jewish communities were sovereign, the imposition of wage and price controls was politically possible and yet economically self-defeating. The communal controls may lie in desuetude today, but we should admit that when they were effective, they were based on erroneous economic science. If it ever becomes politically feasible to enforce these communal pricecontrols again, we should be ready to criticize that power immediately.

Finally, there is one general solution to these problems which may prove useful. While Jewish tradition holds the Talmudic sages received a tradition of Jewish law that dates back to the revelation at Sinai - the Torah She'be'al Pe ("Oral Law") - and which was embodied in the Talmud, there is also a tradition - albeit less universally accepted - that this Sinaitic Oral Law did not include scientific knowledge (Talmud, Pesahim 94b, quoted in Levi 2006 [1983]: 223f. and in Hirsch n.d.: 21, cited in Angel 2008: 16; Sherira Gaon, Otzar ha-Geonim, Gittin 68, par. 376, quoted in Levi 2006 [1983]: 223 and in Student 2001; Maimonides, Moreh Nevukhim, pt. 3, end of ch. 14, quoted in Levi 2006 [1983]: 
223 and in Student 2001; Avraham ben ha-Rambam in Glick 1916: vii; Hirsch in Breuer 1975, Hirsch n.d.: 19, and Levi 2006 [1983]: 225; Haim David Halevy, Asei Lekha Rav 5:49, quoted in Angel 2008: 16; Schachter 2014; Student 2001; Lew 1985: 3; cf. Student 2014). According to this view, the Talmudic sages combined their Sinaitic legal traditions with whatever knowledge of contemporary, secular science they possessed, to arrive at practical legal decisions. Therefore, their practical legal decisions could prove to be incorrect insofar as they were based - in good faith - on inaccurate scientific knowledge of the time. According to many - not all - contemporary Jewish legal authorities, it is sometimes - not always - permissible or even mandatory to change Jewish law whenever it is discovered that the scientific knowledge on which the law was based, is not accurate (Schachter 2014, Student 2001, Levi 2006 [1983]: 228; for the contrary view of Maimonides, see Buchman 2007, Glasner 1921, Student 2001). However, whether any particular halakhah can be altered in accordance with new scientific discoveries depends on the precise relationship between the specific halakhah in question and the related scientific principle; whether the halakhah may be modified must be decided on a case-by-case basis (Schachter 2014, Student 2001, Levi 2006 [1983]: 228). Therefore, we cannot simply state categorically that all these halakhic economic regulations were definitely based on ancient, inaccurate understandings of economics; nor can we automatically conclude that these halakhot may be summarily abolished. But we can state that it is possible that these halakhot may be abolished on this basis. This deserves further study.

\section{Conclusion}

Thus, we have seen that the halakhah's economic regulations, like all forms of price-control, would tend to be inefficient if enforced and would tend to accomplish the very opposite of their intention. While ona'ah may have only been intended to protect against asymmetric information, the hafka'at she'arim / hayyei nefesh ordinance definitely constitutes a self-defeating price-control on essential foodstuffs. And the community's power to impose wage and price controls cannot be 
explained anyway as being anything but a similarly self-defeating price-control. Aaron Levine's attempt to defend hayyei nefesh as being something other than a price-control is unconvincing. We have demonstrated that positive (value-free) science may contradict religion, not only in the realm of cosmology and biology, but even in the area of economics.

But it may be the case that the law of hafka'at she'arim / hayyei nefesh is no longer applicable to a modern marketplace, and therefore, it may be no cause for concern. If so, then the matter may rest there. Meanwhile, the corporate Jewish community luckily appears to no longer possess the legal or political authority to exercise its power to impose wage and price controls, but we should still criticize that theoretical power in case the community ever regains its authority. In all these cases, it is possible but not guaranteed, that some of these laws may be able to be abolished or nullified on the grounds that they were based, not on Sinaitic legal tradition, but on then-contemporary scientific understanding which has proven to be inaccurate.

\section{Acknowledgments}

This paper is an abridged version of the author's senior undergraduate thesis (May 2015), written under the direction of Prof. Walter E. Block (Loyola University, New Orleans). Brief passages in this paper are adapted with permission from previously published work by Block $(1986,1990,2002)$. Research assistance and guidance was provided by Naomi Yavneh, Teri Gallaway, and Elizabeth Kelly. James Bailey, Christopher Surprenant, Phil Magness, and Isaac Morehouse offered comments on a prospectus of this paper which the author presented at the IHS (Institute for Humane Studies) Undergraduate Research Colloquium in New Orleans on 24 Oct. 2014. The author acknowledges the receipt of a stipend from IHS funding his travel expenses to that colloquium. Peter Lewin read and commented on a draft. 
Acton, Lord (John Emerich Edward Dalberg). (1887), "Letter to Archbishop Mandell Creighton," $<\underline{\text { http://oll.libertyfund.org/titles/acton-acton-creighton-correspondence\#lf1524_label } 010>}$ [accessed: 29 Jan. 2016]

Angel, Marc D. (2008), "Reflections on Torah Education and Mis-Education," Tradition 41:2 $<\underline{\text { http://traditionarchive.org/news/article.cfm?id=105346 }}>$ [accessed: 3 December 2014] $<$ http://www.jewishideas.org/min-hamuvhar/reflections-torah-education-and-mis-education $>$ [accessed: 3 December 2014]

Armentano, Dominick T. (1972), The Myths of Antitrust, New Rochelle, NY: Arlington House. idem. (1982), Antitrust and Monopoly: Anatomy of a Policy Failure, New York, NY.: Wiley. idem. (1991), Antitrust Policy: The Case for Repeal, Washington, DC: Cato Institute. Block, Walter. (1986), “Comment” in Block and Hexham 1986: 432-449. This is a direct reply to Tamari 1986. A "Discussion" followed in the same volume (pp. 450-461). idem. (1990), "Jewish Economics in the Light of Maimonides", International Journal of Social Economics 17(3): $60-68<\underline{\text { http://ssrn.com/abstract=1896480 }}>$ [accessed: 20 Oct. 2014] idem. (2002), “Ona'ah”, International Journal of Social Economics 29(9): 722-729

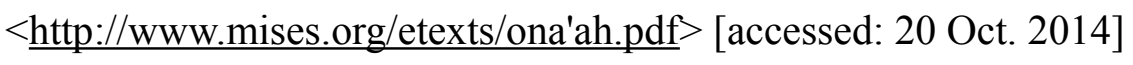
Block, Walter; Geoffrey Brennan; and Kenneth Elzinga (eds.). (1985), Morality of the Market: Religious and Economic Perspectives: Proceedings of an International Symposium, Vancouver, Fraser Institute. (Proceedings of the 9-11 August 1982 Liberty Fund, Inc. symposium on "Religion, Economics, and Social Thought.")

Block, Walter and Irving Hexham (ed.). (1986), Religion, Economics and Social Thought: Proceedings of an International Symposium, Vancouver: Fraser Institute. (Proceedings of the 9-11 August 1982 Liberty Fund, Inc. symposium on “Religion, Economics, and Social Thought.”) Boudreaux, Donald J. and DiLorenzo, Thomas J. (1992), “The Protectionist Roots of Antitrust," Review of Austrian Economics 6(2): 81-96. 
Breuer, Mordechai (ed.), (1975), "Ma'amar Rav Shimshon Raphael Hirsch, zatza"l al Aggadot Hazal”, Ha-Ma'ayan (Tevet 5736): 1-6

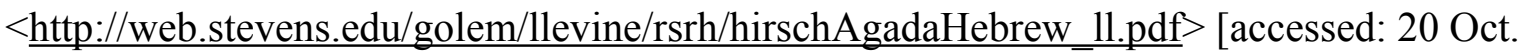
2014]; trans. in Hirsch (n.d.).

Buchman, Asher Benzion. (2007), "Rationality and Halacha: The Halacha L'Moshe MiSinai of Treifos," Hakirah: The Flatbush Journal of Jewish Law and Thought vol. 4: 121-135.

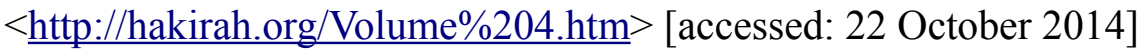

Caplan, Bryan. (2007), The Myth of the Rational Voter: Why Democracies Choose Bad Policies, Princeton, NJ: Princeton University Press.

Cornell, Nina W. and Douglas W. Webbink. (1985), "Public Utility Rate-of-Return Regulation: Can It Ever Protect Customers?," in Robert W. Poole, Jr. (ed.), Unnatural Monopolies: The Case for Deregulating Public Utilities, Lexington, Massachusetts / Toronto, Canada: Lexington Books: 27-47.

Coyne, Christopher and Rachel Coyne. (ed.) (2015a), Flaws and Ceilings: Price Controls and the Damage they Cause, London: Institute of Economic Affairs (IEA).

idem. (2015b), "The economics of price controls," in Coyne and Coyne (2015b: 29-44).

DiLorenzo, Thomas J. (1988), "Property Rights, Information Costs, and the Economics of Rent Seeking. Journal of Institutional and Theoretical Economics (JITE)/Zeitschrift für die gesamte Staatswissenschaft: 318-332.

idem. (1997), “The Myth of Natural Monopoly,” Review of Austrian Economics 9(2): 43-58.

Elon, Menachem. (2008), “Hafka'at She'arim”, rpt. from the Encyclopedia Judaica, $2^{\text {nd }}$ ed. $<\underline{\text { http://www.jewishvirtuallibrary.org/jsource/judaica/ejud } 00020008 \quad 0 \quad 08134 . h t m l}>$ [accessed: 20 Oct. 2014]

Epstein, Isidore. (1962), "Social Legislation in the Talmud", rpt. from the Soncino Talmud

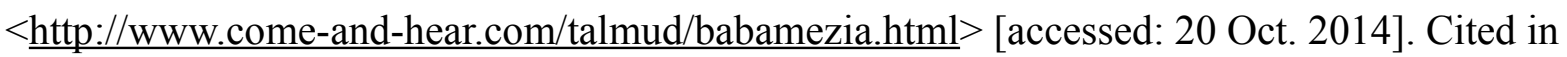


Alan Brill 2012a.

Eretz Hemdah. (2009), “Hemdat Hadaf Hayomi: Calculation of Ona'ah,” Eretz Hemdah (28 Sivan

5769) $<\underline{\text { http://eretzhemdah.org/newsletterArticle.asp? }}$

$\underline{\text { lang}=\text { en \&pageid }=48 \& \text { cat }=7 \& \text { newsletter }=765 \& \text { article }=2902}>$ [accessed: 22 Oct. 2014$]$

Folsom, Burton W. (2010 [1987]), The Myth of the Robber Barons: A New Look at the Rise of Big

Business in America, Hemdon: VA, Young America's Foundation. (Orig. Entrepreneurs vs. the

State: A New Look at the Rise of Big Business in America, 1840-1920, Herndon, VA: Young

America's Foundation.)

Friedman, Menachem. (1982), “The Changing Role of the Community Rabbinate,” Jerusalem

Quarterly 25 (Fall): 79-99.

idem. (1986), “Haredim Confront the Modern City,” Studies in Contemporary Jewry vol. 2, ed. Peter Y.

Medding, Bloomington: Indiana University Press: 74-96.

idem. (1993), "The Market Model and Religious Radicalism," Jewish Fundamentalism in a

Comparative Perspective: Religion, Ideology, and the Crisis of Modernity, ed. Laurence J.

Silberstein (ed.), New York \& London: New York University Press: 192-215.

idem. (2004), "Halachic Rabbinic Authority in the Modern Open Society," Jewish Religious

Leadership, Image, and Reality, vol. 2, ed. Jack Werthheimer, New York: Jewish Theological Seminary: 757-770.

Glasner, Moshe Shmuel (1921), “Haqdama” to the Dor Revi'i, Klausenburg. An abridged translation may be found in Yaakov Elman, (1991), "From the Pages of Tradition: Rabbi Moses Samuel Glasner: The Oral Torah," Tradition 25(3) (Spring): 63-69. It is translated unabridged by David Glasner (unpubl.). "Haqdamah to Dor Revi'i."

Glick, Shmuel Tzvi-Hirsch (ed. \& trans.). (1916): En Jacob: Agada of the Babylonian Talmud, vol. 1, no publ. The section cited is online at

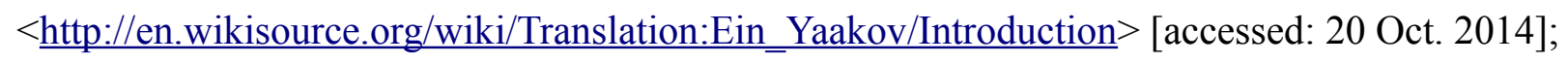


cf. the alternate trans. of Avraham Yaakov Finkel

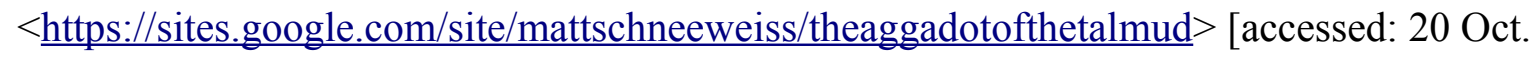
2014]

Goldstein, Warren. (2006), Defending the Human Spirit: Jewish Law's Vision for a Moral Society, Jerusalem / New York: Feldheim.

Gorman, Linda. (2008), "Discrimination," The Concise Encyclopedia of Economics, Library of

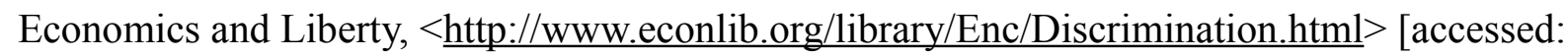
29 Jan. 2016].

Hayek, F. A. (2007 [1944]), The Road to Serfdom: Text and Documents--The Definitive Edition, Chicago: University of Chicago Press. (Orig. Chicago: University of Chicago Press, 1944.) Hirsch, Samson Raphael. (n.d.), "Rabbi Samson Raphael Hirsch: Trusting the Torah's Sages” (unattributed translation of Breuer 1975), Light Magazine

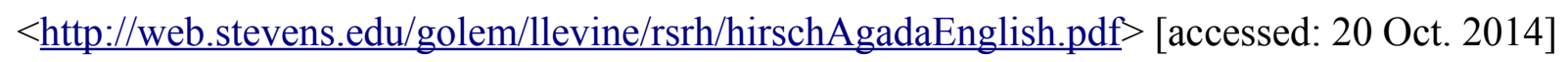
Holcombe, Randall G. (2014), “The Common Pool of Transitional Profits,” Review of Austrian Economics 27(4): 387-401.

Jefferson, Thomas. (1798), "The Kentucky Resolution of 1798,"

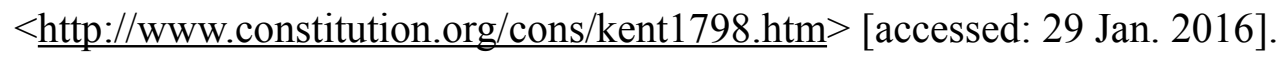

Jewish Encyclopedia (1906), "Ona'ah" < $\underline{\text { http://www.jewishencyclopedia.com/articles/11707-ona-ah> }}$ [accessed: 20 Oct. 2014]

Kirzner, Israel M. (1973), Competition and Entrepreneurship, Chicago, IL: University of Chicago Press.

idem. (1997), How Markets Work: Disequilibrium, Entrepreneurship and Discovery, London: Institute of Economic Affairs.

Kleiman, Ephraim. (1987), “'Just Price' in Talmudic Literature,” History of Political Economy 19(1): $23-45$ 
Kolko, Gabriel. (1963), The Triumph of Conservatism: A Reinterpretation of American History, 19001916, NY: Free Press of Glencoe.

Krueger, Anne O. (1974), “The Political Economy of the Rent-Seeking Society,” American Economic Review 64(3) (June): 291-303.

Leoni, Bruno. (2009 [1965]), “The Myth and Reality of Monopolies,” in Carlo Lottieri (ed.), Law, Liberty, and the Competitive Market, New Brunswick, NJ: Transaction: 83-104.

Levi, Yehudah (Leo). (2006 [1983]), Torah and Science: Their Interplay in the World Scheme, Jerusalem, Israel: Feldheim.

Levine, Aaron. (1985a), “Comment,” in Block, Brennan, and Elzinga (1985): 419-429.

idem. (1985b), “Discussion,” in Block, Brennan, and Elzinga (1985): 446-449.

idem. (2012), Economic Morality and Jewish Law, Oxford: Oxford University Press.

Littlechild, S. C. (2009 [1978]), The Fallacy of the Mixed Economy: An 'Austrian' Critique of Recent Economic Thinking and Policy, London: Institute of Economic Affairs.

Madison, James. 1788. The Federalist, no. 51. New York, The Independent Journal, Feb. 6th.

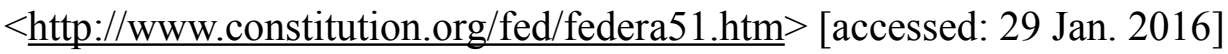

McGee, John S. (1958), “Predatory Price Cutting: The Standard Oil (N.J.) Case,” Journal of Law and Economics 1 (October): 144-58.

Morton, Fiona M. Scott. (2001), “The Problem of Price Controls,” Regulation 24:1 (Spring): 50-54. $<$ http://object.cato.org/sites/cato.org/files/serials/files/regulation/2001/4/morton.pdf $>$ [accessed: 15 March 2015]

Pasour Jr, E. C. (1987), "Rent Seeking: Some Conceptual Problems and Implications.” The Review of Austrian Economics 1(1): 123-143.

Pennington, Mark. (2011), Robust Political Economy: Classical Liberalism and the Future of Public Policy, Cheltenham, UK / Northampton, MA, USA: Edward Elgar.

Posner, Richard. (1974), “Theories of Economic Regulation,” Bell Journal of Economics and 
Management Science 5(2) (Autumn): 335-358.

Ricketts, M. (1987), “Rent Seeking, Entrepreneurship, Subjectivism, and Property Rights.” Journal of Institutional and Theoretical Economics (JITE)/Zeitschrift für die gesamte Staatswissenschaft: 457-466.

Roback, Jennifer. (1986), "The Political Economy of Segregation: The Case of Segregated Streetcars.” Journal of Economic History 56(4) (December): 893-917.

Rockoff, Hugh. (2008), "Price Controls." The Concise Encyclopedia of Economics. Library of Economics and Liberty. $<$ http://www.econlib.org/library/Enc/PriceControls.html $>$ [accessed: 15 March 2015]

Schachter, Hershel. (2014), "Science and the Sages," Jewish Action (winter): 50.

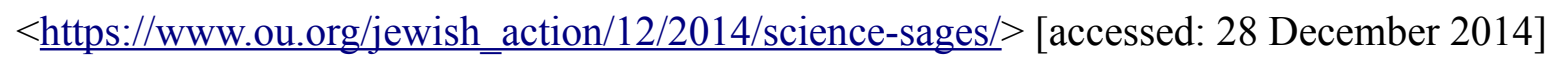

Schuettinger, Robert L. and Eamonn F. Butler. (1979), Forty Centuries of Wage and Price Controls: How Not to Fight Inflation, Washington, DC: The Heritage Foundation.

Sharfman, Keith (2006), "The Law and Economics of Hoarding," 19 Loyola Consumer Law Review

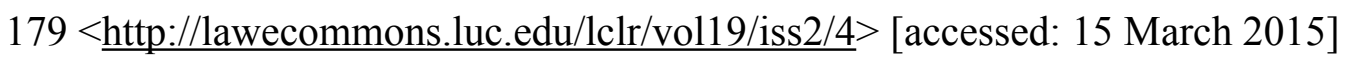

Shilo, Shmuel and Menachem Elon. (2008), “Ona'ah”, rpt. from the Encylopedia Judaica, $2^{\text {nd }}$ ed. $<\underline{\text { http://www.jewishvirtuallibrary.org/jsource/judaica/ejud_0002_0015_0 } 0015103 . h t m l}>$ [accessed: 20 Oct. 2014]

Slifkin, Natan. (2006), The Challenge of Creation: Judaism's Encounter with Science, Cosmology, and Evolution, Springfield, NJ \& Jerusalem, Israel: Gefen.

Stigler, George. (1971), “The Theory of Economic Regulation,” Bell Journal of Economics and Management Science 2 (Spring): 3-21.

Student, Gil. (2001), "Halachic Responses To Scientific Developments”, $<$ http://www.aishdas.org/toratemet/science.html> [accessed: 20 Oct. 2014] 
idem. (2014), "New Science, Same Torah," Jewish Action (winter): 48-49, 51-55 (p. 50 is Schachter 2014). $<$ https://www.ou.org/jewish_action/12/2014/new-science-torah/> [accessed: 28

December 2014]

Tamari, Meir. (1986), “Judaism and the Market Mechanism” in Block and Hexham 1986: 393-420. Block 1986 is a direct reply and a "Discussion" followed in the same volume (pp. 450-461). idem. (1987), “With All Your Possessions”: Jewish Ethics and Economic Life, NY, NY: Free Press. idem. (1991), In the Marketplace: Jewish Business Ethics, Southfield, Michigan: Targum / Spring Valley, NY: Feldheim.

Tullock, Gordon. (1967). “The Welfare Costs of Tariffs, Monopolies, and Theft.” Western Economic Journal 5:3 (June): 224-232. Rpt. in Virginia Political Economy (The Selected Works of Gordon Tullock vol. 1, ed. Charles K. Rowley). Indianapolis, Indiana: Liberty Fund: 169-179.

Warhaftig, Itamar. (1987), “Consumer Protection: Price and Wage Levels,” Crossroads: Halacha and the Modern World, Vol. 1 Alon Shvut-Gush Etzion, Israel: Zomet Institute.

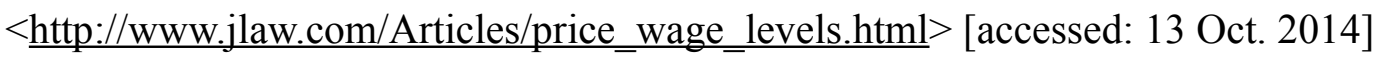

idem. (1988), “Consumer Protection: Price Fraud," Crossroads: Halacha and the Modern World, Vol. 2 Alon Shvut-Gush Etzion, Israel: Zomet Institute.

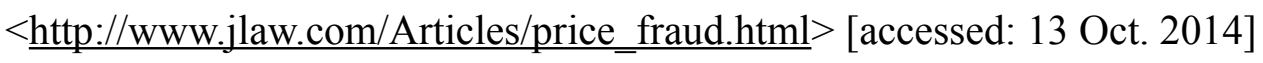

Weissman, Seth Winslow. (1998), Price Matching From Roman Palestine to Today: Rationing Refunds to Reverse the Anti-Competitive Effects of Price Matching. Unpublished PhD thesis, Columbia University. UMI Microform no. 9839021. 
1 For a comprehensive review of Jewish responses to this conflict, see Slifkin (2006). For a review of the different traditional Jewish approaches to science in general, see Levi (2006 [1983]).

2 The principle sources from which this summary is drawn are Elon (2008), Shilo and Elon (2008), the Jewish Encyclopedia (1906), Tamari (1991: 68-91, 1987: 88-100), Warhaftig (1987, 1988), Weissman (1998), Levine (2012:93-116), Kleiman (1987), Lew (1995:42f.), and Epstein (1962).

3 According to Levine (2012: 93, $112 \mathrm{n}$. 2), the one-sixth measurement is calculated by what is called an "outside sixth" or an "inside fifth," meaning that if the price is $\$ 10$, the forbidden deviation is a fifth of $\$ 10$ ("inside"), i.e. $\$ 2$, with the $\$ 2$ discrepancy being one-sixth of the resulting $\$ 12$ ("outside"). So too Warhaftig (1987: sec. 4, "Profit Limitation"). Therefore, the one-sixth (outside) limitation is sometimes referred to as a $20 \%$ (inside) limitation. However, Tamari's illustrative examples (1991: 79) show that he regards the one-sixth as being "inside" not "outside." Kleiman (1987: 31) is uncertain which standard to apply. Eretz Hemdah (2009) says that the Talmud presents both possibilities, with post-Talmudic commentators discussing when to apply which. In Hil. Mekhira 12:2, Maimonides appears to shift from one fraction to another silently, with his examples of prohibited ona'ah varying from $+1 / 5$ to $-1 / 7$ to $\pm^{1 / 6}$.

4 Levine (2012: 95) notes three different views on which specific types of foodstuffs are priceregulated. Cf. Warhaftig (1987: s.v. "2. Products Included").

5 For example, Sharfman (2006) uses the Weitzman model to defend the Talmud's restrictions on speculation. According to Sharfman, restrictions on speculation are beneficial if one takes for granted as given that there is a preexisting price-control in place which cannot be repealed. Therefore, Sharfman points to the existence of the ona'ah law - which he considers to be a pricecontrol - as justifying further restrictions on speculation. However, Sharfman (2006: 192) has difficulty with the fact that the Talmud's restrictions on speculation apply only to foodstuffs, while ona'ah applies to nearly all goods whatsoever. Sharfman's explanation is forced, and his confusion 
would not have arisen if he had known that the hayyei nefesh law, which is very similar to ona'ah, does apply exclusively to foodstuffs. Furthermore, since we shall find that ona'ah is not a pricecontrol while hayyei nefesh $\underline{i s}$ one, then assuming price-controls do indeed justify restrictions on speculation, Sharfman definitely should have appealed to hayyei nefesh, not ona'ah.

6 Levine adumbrates an interpretation like this (1985a: 423; 1985b: 448), but he does not elaborate or explain, only saying laconically that the law of $o n a^{\prime} a h$ is based on the absence of perfect knowledge in the marketplace.

7 One might still object that it is immoral and inexpedient to disincentive research by requiring merchants to disclose gratis the results of their costly market research (Block 1986, 1990, 2002). Furthermore, the law of $o n a^{\prime} a h$ presumes that some "true" market price does exist, which the merchant must disclose. According to Warhaftig (1988 s.v. "A. Definition”), one of the "assumptions at the base of this law" is that "there exists a standard market price from which the sale price deviated by a sixth or more." But in fact, no such "standard market price" can possibly exist, and it is impossible to distinguish meaningfully between the generalized market price and the specific sale price. This is because every good and every transaction is unique. Scientifically speaking, there is only one way to determine the market price: find out the latest terms of sale. Therefore, it is impossible to achieve full-disclosure that is in compliance with the law of ona'ah; no merchant is capable of disclosing a discrepancy from a nonexistent "true" price. As Warhaftig (1988 s.v. "G. Contemporary Application") notes, the assumption of " $[\mathrm{t}]$ he existence of a market price for the product ... [is] problematic in a modern market" because "we [cannot] speak of a market price today, when prices change from place to place and from time to time. . . [I]n a completely free market, where every merchant has his own price[, $t]$ here is is no market price, and therefore no ona'ah." Likewise, Elon says (in Shilo and Elon 2008), “These conditions severely impede the implementation of the law in our times, as the vast majority of items sold do not have a fixed, uniform price, and prices may vary considerably from place to place and among different vendors." 
8 For analysis and critique of price-controls in general, see Coyne and Coyne (2015a), Schuettinger and Butler (1979), Morton (2001), Rockoff (2008), and Levine (2012: 93-95).

9 Concerning ona'ah, Levine adumbrates (1985a: 423; 1985b: 448) the interpretation which we gave to that law - viz. that ona'ah is only meant to promote the dissemination of information - but he does not elaborate or explain.

10 The same statement occurs verbatim twice.

11 The same statement occurs verbatim twice.

12 The same statement occurs verbatim twice.

13 The same difficulty exists in Tamari (1987: 95): "the seller is bound by these fixed prices as long as they are operative. Should prices rise ... the seller is free to charge whatever he wishes...”. Likewise, Warhaftig (1987: end of sec. “4. Profit Limitation”): “The law applies only if the present market price is unchanged. If the price has risen, he may sell at the prevailing price even though he will thereby profit more than a sixth." What sense does it make to say that prices are fixed only so long as they do not change, but that once they change, they are no longer to be fixed?

14 Meanwhile, Tamari and Warhaftig would say that once the market price rises beyond $\$ 10$, sellers may sell for whatever price they want (see previous note).

15 The same identical passage occurs on both pp. 109 and 112.

16 Cf. Levine (1985a: 423): "the constraint amounts to nothing more than a restraint on economic rent" and Levine (1985b: 448): "what it amounts to is really a restraint on economic rent."

17 Cf. Tamari's (1991: 69) assertion that trade restrictions are legitimate where the merchant is "earning excessive profits or where there is no benefit to the consumer."

18 For a criticism of the Neoclassical static-equilibrium theory of monopoly, see Leoni (2009 [1965]). That it would be impossible to rationally rate-regulate a monopoly for the same reasons that economic calculation is impossible under socialism, see Cornell and Webbink (1985: 44 n. 16). And according to Kirzner's theory of the market as a "process" (following Mises), the dynamic market 
process is itself the solution to so-called market failures, including monopoly and excess profits (Kirzner 1997, Littlechild 2009 [1978], DiLorenzo 1988: 321f., Pasour 1987: 124-126).

Furthermore, monopoly is typically a consequence of government regulation and intervention, not the operation of the free-market (Hayek [2007] 1944 ch. 4 [“The Inevitability of Planning”]; McGee 1958; Kolko 1963: ch. 1-2; Leoni 2009 [1965]; Stigler 1971; Posner 1974; Folsom 2010 [1987]; Armentano [1972, 1982, 1991], Boudreaux and DiLorenzo [1992], DiLorenzo [1997]). Therefore, Levine should have said that the modern equivalent of hafka'at she'arim is not to tax the excess profits of a monopolist, but rather to repeal the government intervention which creates the monopoly. If monopolies are actually a consequence of government intervention, then it would make more sense to interpret hafka'at she'arim instead as a ban on rent-seeking (Tullock 1967, Krueger 1974) and government regulations which insulate corporations from competition (Stigler 1971, Posner 1974), allowing them to earn monopoly rents. That above-normal returns to entrepreneurship are sometimes wrongfully diagnosed as monopoly rents obtained through rentseeking, see DiLorenzo (1988: 321f.) and Pasour (1987: 124-126); cf. Ricketts (1987). 